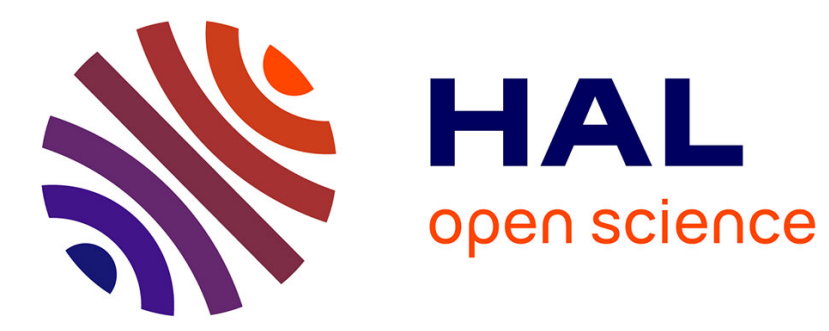

\title{
Effective resolution in ocean models
}

Patrick Marchesiello, Yves Soufflet, Xavier Capet, Julien Jouanno, Florian Lemarié

\section{To cite this version:}

Patrick Marchesiello, Yves Soufflet, Xavier Capet, Julien Jouanno, Florian Lemarié. Effective resolution in ocean models. EGU General Assembly 2014, Apr 2014, Vienna, Austria. 2014. hal-01062950

\section{HAL Id: hal-01062950 https://hal.inria.fr/hal-01062950}

Submitted on 11 Sep 2014

HAL is a multi-disciplinary open access archive for the deposit and dissemination of scientific research documents, whether they are published or not. The documents may come from teaching and research institutions in France or abroad, or from public or private research centers.
L'archive ouverte pluridisciplinaire HAL, est destinée au dépôt et à la diffusion de documents scientifiques de niveau recherche, publiés ou non, émanant des établissements d'enseignement et de recherche français ou étrangers, des laboratoires publics ou privés. 


\section{Effective resolution in ocean models}

Patrick Marchesiello (1), Yves Soufflet (1), Xavier Capet (2), Julien Jouanno (1), and Florian Lemarie (3)

(1) IRD, LEGOS, Toulouse, France (patrick.marchesiello@ird.fr), (2) CNRS, LOCEAN, Paris, France, (3) INRIA, LJK, Grenoble, France

The increase of model resolution naturally leads to the representation of a wider energy spectrum. As a result, in recent years, the understanding of oceanic submesoscale dynamics has significantly improved. Also, the ubiquity of upper ocean frontal dynamics driving a direct energy cascade is now acknowledged. In the forward cascade framework, numerical and physical closures are more consistent in principle, but dissipation in submesoscale models remains dominated by numerical constraints rather than physical ones. Therefore, effective resolution can be defined by its numerical dissipation range, which is a function of the model numerical filters (assuming that dispersive numerical modes are efficiently removed).

The COMODO project gathers the whole French ocean modeling community in order to assess current numerical methods and guide the development of future models. Within this framework, we present an idealized ACC-type Jet case, which provides a controllable test of a model capacity at resolving submesoscale dynamics. We compare analyses performed on simulations from two models, ROMS and NEMO, at different mesh sizes (from 20 to $1 \mathrm{~km}$ ). Through a spectral decomposition of kinetic energy and its budget terms, we identify the characteristics of turbulent cascade, numerical dissipation, and effective resolution. It shows that numerical dissipation appears in different parts of a model, especially in spatial advection-diffusion schemes for momentum equations (KE dissipation) and tracer equations (APE dissipation) and in the time stepping algorithms. 